\title{
Geological and Geochemical Investigation of Low Grade Basement Rocks: Implication to Human Health in and around Asgeda Tsimbla, Western Tigray, Northern Ethiopia
}

\author{
Jemal Ahmed1, Kassa Amare ${ }^{2 *}$ \\ ${ }^{1}$ Department of Earth Science, University of Samara, Samara, Ethiopia \\ ${ }^{2}$ Department of Earth Science, University of Mekelle, Mekelle, Ethiopia \\ Email: jemalahmed@su.edu.et,jemal99@yahoo.com,kassamare1@yahoo.com
}

Received 21 May 2016; accepted 21 August 2016; published 25 August 2016

Copyright (C) 2016 by authors and Scientific Research Publishing Inc.

This work is licensed under the Creative Commons Attribution International License (CC BY). http://creativecommons.org/licenses/by/4.0/

(c) (;) Open Access

\section{Abstract}

The increase in the number of liver related disease patients from north western region of Ethiopia has been an environmental health issue of national concern. As the disease is restricted to a specific geographical terrain, particularly to Shire area, northwestern dry zone of the country, detail research studies are required to identify possible etiology and risk factors. The aim of the study is to determine the level of trace element and heavy metal concentrations and distributions in water and stream sediments of the area and identify the possible sources in relation to human health. During the study, geochemical sampling (20 water, 20 stream sediment and 6 rock samples) was carried out in March 2011. The collected samples were analyzed for their major and trace element contents using ICP-MS, ICP-OES, Ion Chromatography (IC), and XRF. Analytical data were organized and treated using Excel, SPSS, ArcGIS and Aquachem softwares. Analytical data results with respect to trace element contents in surface and ground waters are compared with the Maximum Acceptable Concentration or Maximum Allowable Concentration (MAC) of World Health Organization (WHO) and Ethiopian standards for drinking water. The comparison reveals that there are problematic elements that pass over the quality standards set for drinking water. One of these is: Bromine (Br), for which $100 \%$ all samples have value above $0.01 \mathrm{mg} / \mathrm{l}$ and up to $1.475 \mathrm{mg} / \mathrm{l}$. Other problematic elements including aluminum (Al) $-30 \%$, fluorine $(\mathrm{F})-20 \%$, arsenic $(\mathrm{As})-10 \%$, and nitrate $\left(\mathrm{NO}_{3}\right)-10 \%$ are examples of elements which have above WHO-MAC for drinking water. Selenium (Se) deficiency may be the other problematic element in the area for its deficiency is associated with liver damage and heart muscle disorder. The metal contaminations (i.e. heavy metals) were also evaluated by world geochemical background value in average shale and sediment quality guideline proposed by US EPA. The concentration of $\mathrm{Co}$ and $\mathrm{Cr}$ exceeded average shale

\footnotetext{
${ }^{*}$ Corresponding author.
} 
value at most sample stations indicated that these stations ware in potential risk. Geochemical factors are mostly considered to explain the etiology of this liver related disease.

\title{
Keywords
}

\author{
Liver Disease, Environmental Health, Geochemical Survey, Maximum Acceptable \\ Concentration (MAC)
}

\section{Introduction}

Concern over the health of residents of northern Ethiopia-Shire area has been rising in recent years. Health professionals and members of the general public have watched people grow sick with variety of illness; particularly liver related diseases. Interviews with the local people indicated that the liver related diseases were identified in the area since 1980; about 70 people or more have been died so far. Males and females have been equally affected and children aged between 7 and 15 appear to be the most susceptible. With time the rate of disease is increased and affected more people.

In 2006 the Tigay regional Health Bureau sent national task forces (from Ethiopian Health Nutrition and Research Institute (EHNRI), and Addis Ababa University (Tukur Ambessa Hospital) into the area to investigate the cause of this disease. They took plant samples and it was analyzed by national EHNRI laboratory. The result interpreted as a potential toxic plant called “Ageratem” growing around the water source. The "Ageratem” contained a pyrrolizidine alkaloid and the "Gua Kua” disease was a Venue-Occlusive Disease (VOD) of the liver. As a result of this report the water supply in Tsada Emba—north eastern Shire-was filled in and the people internally displaced into the resettlement area in Kelakil—south eastern Shire [1].

No reduction in incidence was noted after the resettlement program. The Tigray health Bureau was forced to question the diagnosis, which led in turn in 2008 to a request to United State Center for Disease Control (CDC) to investigate the crisis in the area. They conducted a case control study and took serum samples, and concluded their report with Schistosomiasis as causative agents [2].

Oasis Foundation of Ethiopia (OFE) made contact with Imperial College of London who ran the Schistosomiasis Control Initiative (SCI). SCI sent a team to investigate a Schistosomiasis, and took (nail, stool and urine) samples and were able to conclude convincingly that Schitosomiasis was not a cause of morbidity [2]. Reports from EHNRI, CDC and SCI was reviewed by professor Thursz from Imperial Collage of London and agreed with the EHNRI reports that the most likely cause would be a Pyrrlizidine alkaloid as originally described with bush tea disease in Jamaica. However, it seemed unlikely that either “Ageratem” or the water supply could be a Pyrrlizidine alkaloid [2].

Since then detail multidisciplinary studies have been conducting to understand the problem from differ scientific point of view and might be resulting in an effective outcome.

In the study area there are abandoned and ongoing artisanal gold mining sites. Many individuals have been panning for gold using manual operations for a long time and there are many intermittent streams in the area into which drainage from gold mining sites flow into main rivers, and this may have led many people to ask whether the illnesses in the community have an environmental cause.

For the protection and conservation of water resource in the study area it is found to be important to characterize the quality of water. Ground water contamination with arsenic, fluoride and nitrate recently possesses serious health hazards to large sector of communities all over the word [3]. Since sediments and suspended particles are important repositories for trace metals such as chromium, copper, molybdenum, cobalt and manganese, studying of sediments of the environment is also found to be vital for characterization of the quality of the environment of the artisanal gold mining sites in and around the study area.

Trace element concentrations in the natural water vary widely depending on the geochemistry of rocks in the immediate environment. Interactions of water and plants with rocks (and soils developed from them) dictate our intake of these elements [4]. So knowledge of rock types in a particular area can help find out potential health problem with concentration of particular elements. 


\section{The Survey Area}

The study area is located about $355 \mathrm{~km}$ northwest of Mekelle, Tigray national state, Northern Ethiopia. Geographically it is located $1,550,000-1,570,000 \mathrm{~m}\left(14^{\circ} 01^{\prime} 12^{\prime \prime}\right.$ to $\left.14^{\circ} 11^{\prime} 54^{\prime \prime}\right)$ north latitudes and 370,000 - 390,000 m (37 $47^{\prime} 48^{\prime \prime}$ to $\left.37^{\circ} 58^{\prime} 54^{\prime \prime}\right)$ east longitudes (Figure 1). Access within the study area is possible through weathered road that connects Shire town to the study area.

The study area is characterized by semiarid to arid climate. The average annual temperature for the region in generally varies from $24^{\circ} \mathrm{C}-29^{\circ} \mathrm{C}$ [5]. Records obtained show temperature maxima between $37^{\circ} \mathrm{C}$ and $40^{\circ} \mathrm{C}$ and minima of $15^{\circ} \mathrm{C}$ to $19^{\circ} \mathrm{C}$. November and December are the coldest months.

The area is generally characterized by rugged topography in its southern and western parts. It has an overall topography that decreases from northeast towards southwest. Metavolcanic and Metagranite generally occupy the high ground while the Metasediments predominantly in the river valleys. The altitude ranges from 1340 to 860 meters above sea level. Streams are intermittent and often drain southwest direction. The drainage pattern is sub dendritic to well developed dendritics. The main streams in the study area are: Mai-Hammar, Mai-Teli, Mai-Weyle, Sembel and Fesfesay rivers.

\section{Methodology}

\subsection{Sampling}

Field was conducted during March 2010. The sampling sites of water and stream sediments were selected based on the distribution of potential pollutant sources.

In conjunction with sampling, close field observations were made on the types of geology, physical land degradation and traditional gold panning practise (Figure 2). Our sampling positions and supplementary information is presented (Figure 3).

Thirteen (13) ground water and Seven (7) surface water samples were taken from deep borehole, shallow hand dug wells, rivers and ponds. Each sample was collected in one-liter polyethylene bottle and the sampling

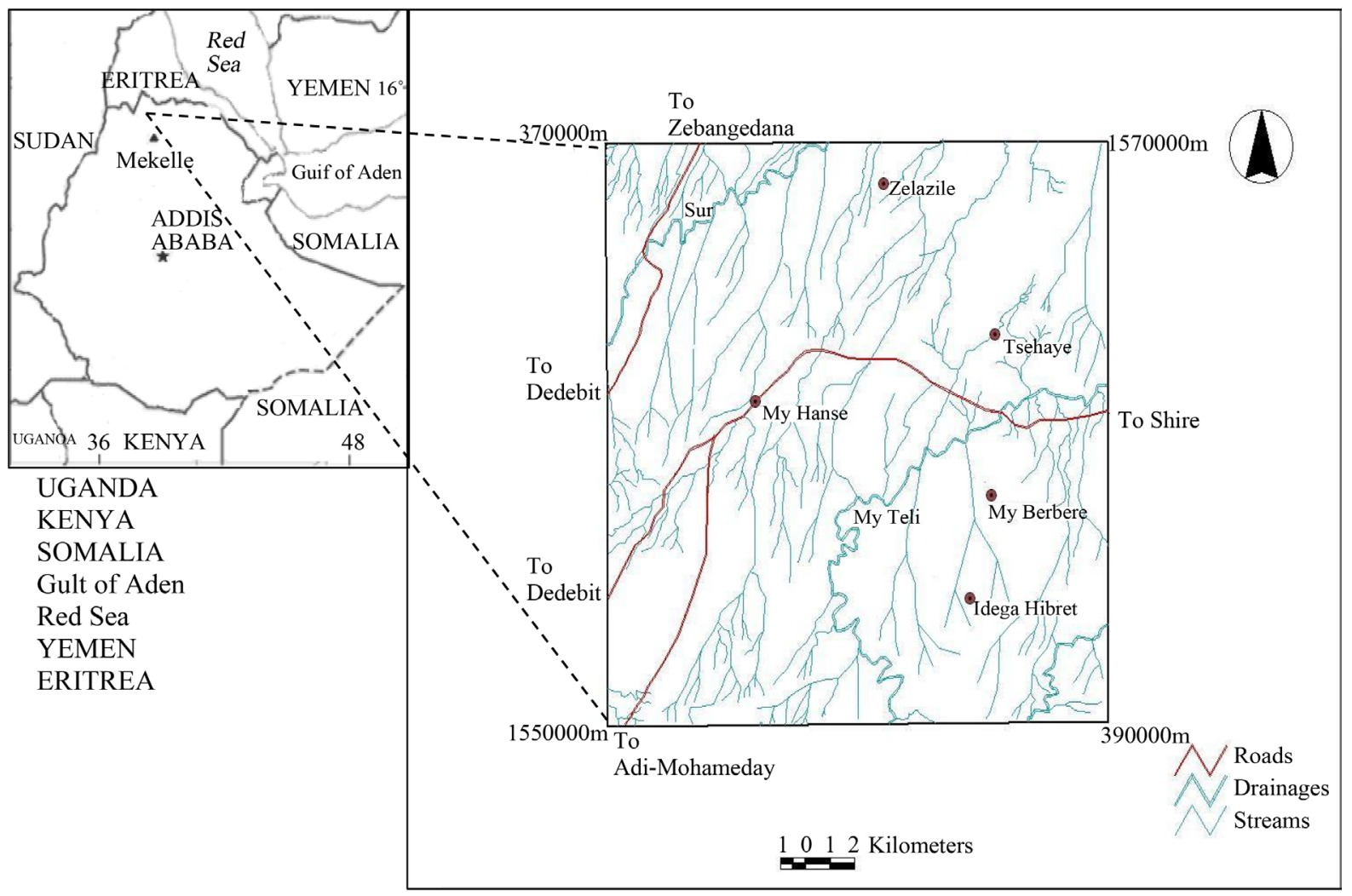

Figure 1. Location map of Asgede Tsimbla sub catchments area. 


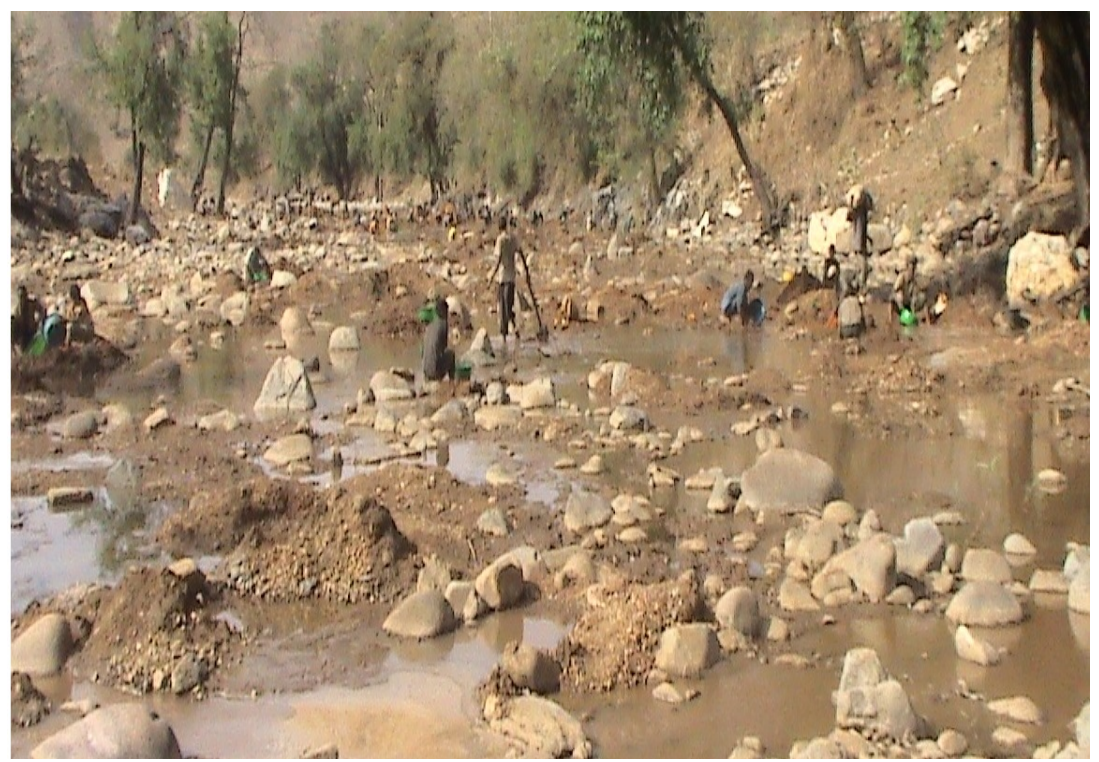

Figure 2. Artesinal gold mining practices in Asgeda Tsimbla sub catchment area.

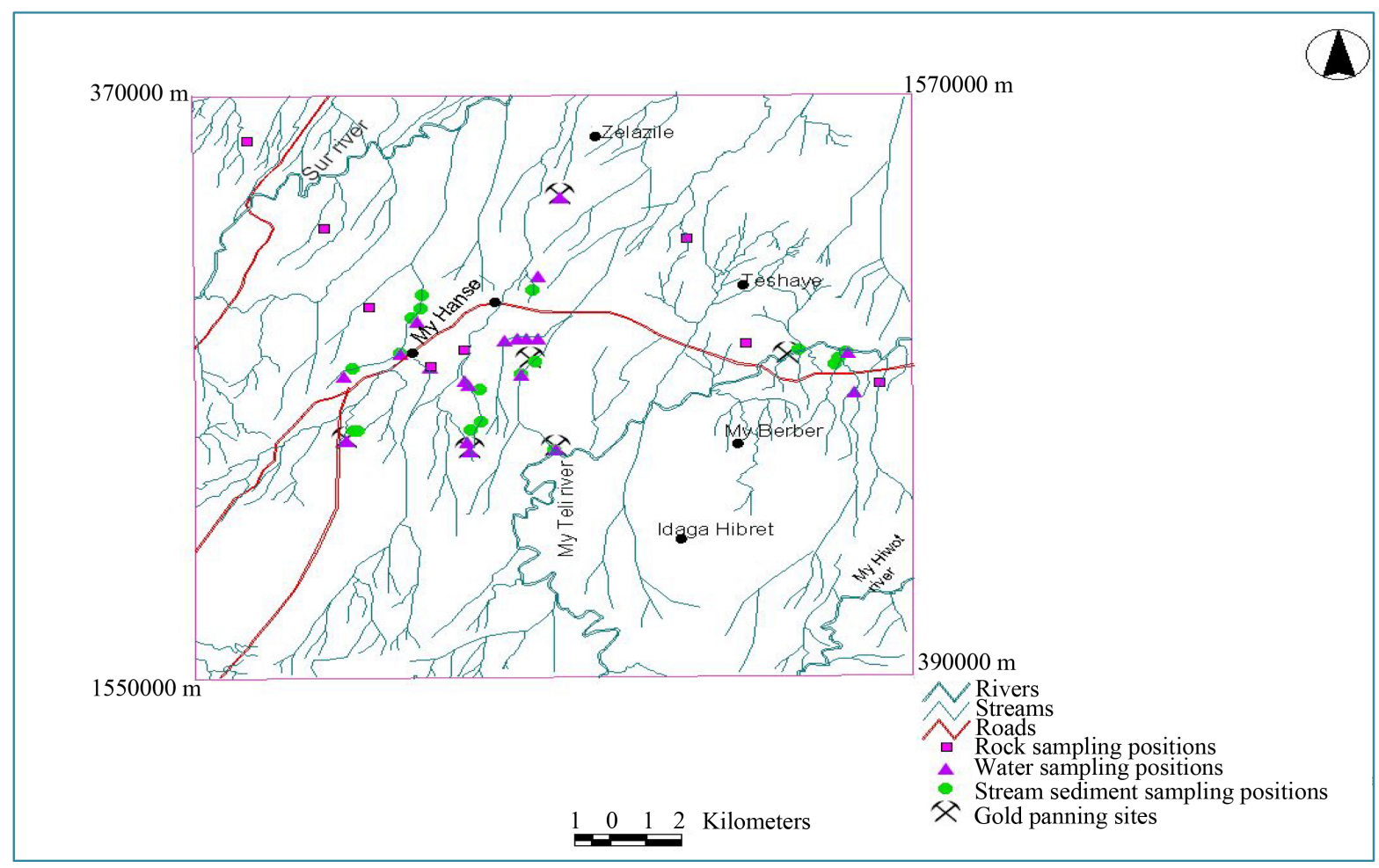

Figure 3. Location map of study area with sample locations and gold panning sites.

bottle was rinsed repeatedly with ground water before taking the samples.

Twenty (20) stream sediment samples were collected from dry and wet stream sediments. Since, some tributaries of seasonal streams have had no water flow for many months: the stream bed was covered by fallen bank materials. The fallen bank material has been removed by digging and the stream sediment was sampled with much care. Most of stream sediment samples were taken from the same site where water sample is collected. About 300 gram the samples were collected using a shovel tool and store in to a clean plastic bags.

Representative rock samples were collected from all mapable units and six of them are selected for thin sec- 
tion and XRF analysis. The lithology, structures, mineralization, quartz veins and alteration intensity of the rocks has been studied in the field. A generalized geological map at 1:50,000 scale is prepared based on the satellite image and field data (Figure 4).

\subsection{Sample Analyses}

The chemical analysis of water samples were carried out in the Institute for Applied Geosciences Laboratory at Graz University of Technology, Austria.

Trace elements (Cd, As, Se, $\mathrm{Pb}, \mathrm{Cr}, \mathrm{Ni}, \mathrm{Cu}, \mathrm{Co} \mathrm{V}, \mathrm{Sr}, \mathrm{Tm}$, and $\mathrm{Ba}$ ) were analysed using Inductively Couple Plasma Mass Spectrometer (ICP-MS; Perkin-Elmer Elan 5000) with ultrasonic nebulization and it was calibrated with multi element standard solutions. Acidified samples were used. The detection limit ranges between 0.01 and $0.1 \mu \mathrm{g} / \mathrm{l}$ and precision also reported as $10 \%$ for numerous trace elements. Major cations $\left(\mathrm{Ca}^{2+}, \mathrm{Mg}^{2+}\right.$, $\mathrm{Na}^{+}$and $\mathrm{K}^{+}$) were analyzed using Inductively Coupled Plasma-Optical Emission Spectrometry (ICP-OES, PERKIN ELMER 4300) and anions $\left(\mathrm{Cl}^{-}, \mathrm{NO}_{3}^{-}\right.$and $\left.\mathrm{SO}_{4}^{2-}\right)$ were measured using Ion Chromatography (IC; DIONEX 600)/HPLC High performance liquid chromatography.

Rock samples were first crushed in stain less steel jaw crusher and then powdered in an agate meal for chemical analysis and the sample preparation for stream sediments also involves drying in an oven, crushing, grinding, sieving with -200 mesh and packing about $100 \mathrm{mg}$ with plastic bags in Ezana Mining Laboratory, Mekelle. Both rock and stream sediment samples have been sent for trace elements (Cd, As, Se, $\mathrm{Pb}, \mathrm{Cr}, \mathrm{Ni}, \mathrm{Cu}, \mathrm{Co} \mathrm{V}$, Sr, Tm, Hg, Ba, Zn, Mn, and Mo) and major oxides $\left(\mathrm{SiO}_{2}, \mathrm{Al}_{2} \mathrm{O}_{3}, \mathrm{Fe}_{2} \mathrm{O}_{3}\right.$, LOI and $\left.\mathrm{MgO}\right)$ analysis using X-Ray Florescence (PHILIPS PW 2404) spectrometer at the laboratory of Institute for Geoscience, Graz University of Technology, Austria. It was done by two methods-pressed powder pellet for trace elements and fussed glass for major oxides. The samples were initially ground and dried at $110^{\circ} \mathrm{C}$ (in fussed glass) and $60^{\circ} \mathrm{C}$ (pressed powder pellet) overnight to remove remaining moisture.

\subsection{Treatments of Analytical Data}

Analytical treatment of data was made in Excel, SPSS, Aquachem and Archview. When analyzing in Aquachem,

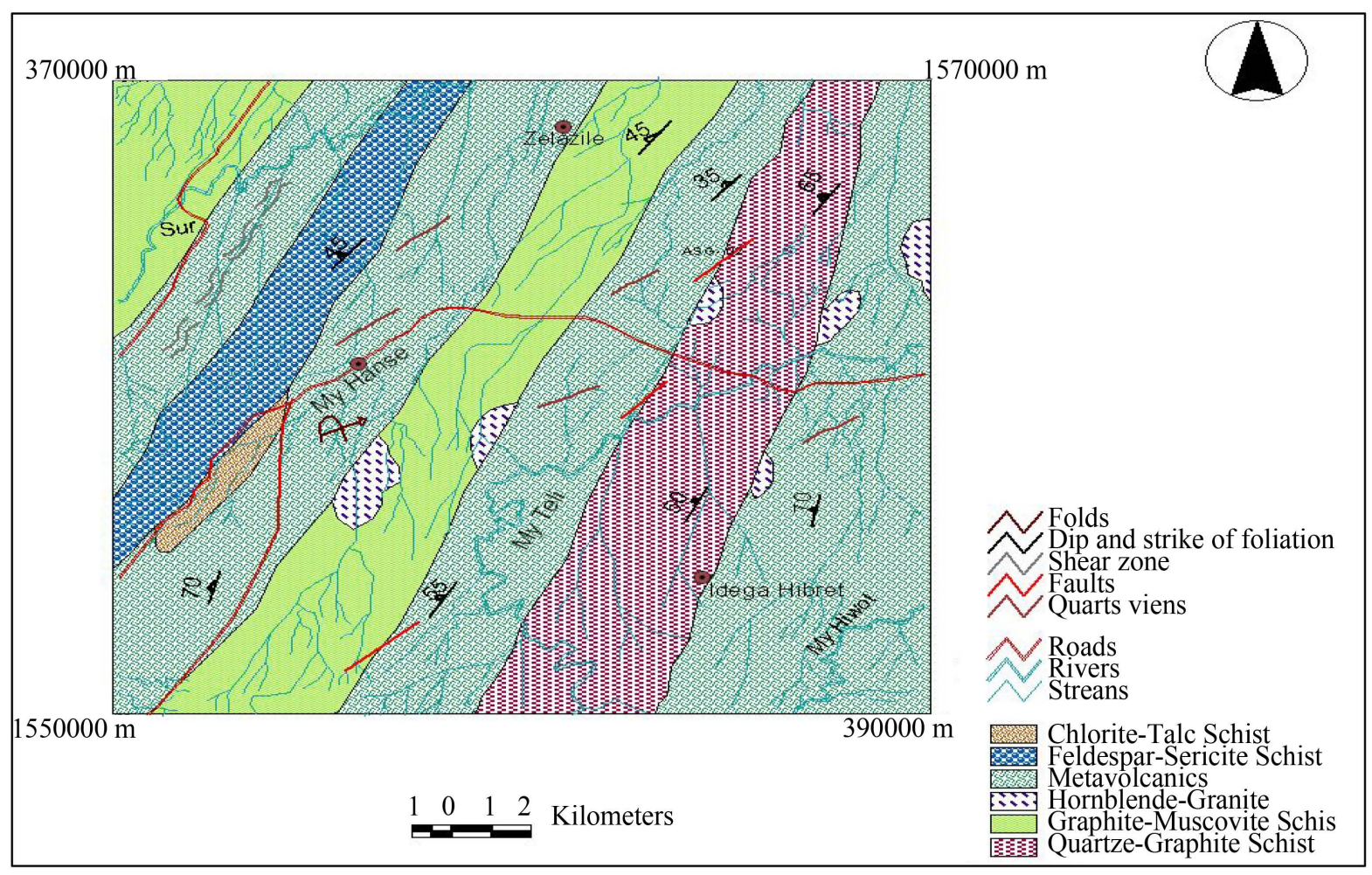

Figure 4. Geological map of Asgede Tsimbla sub catchment area. 
SPSS and Archview value below detection limit level where set to zero. Statistical analysis such as mean, median, standard deviation and multivariate analysis (correlation) were used for data analysis.

\section{Results}

\subsection{Lithogeochemistry}

Major and trace element analysis of some rock samples obtained from the study area was carried out to find out potential health problems associated with concentrations of particular elements (Table 1).

Table 1. Major (wt \%) and trace (ppm) element compositions of selected rock samples in the study area.

\begin{tabular}{|c|c|c|c|c|}
\hline Rock Type & $\begin{array}{l}\text { Graphite Schist } \\
\text { (ATR3) }\end{array}$ & $\begin{array}{l}\text { Graphite-Muscovite-Schist } \\
\text { (ATR5) }\end{array}$ & $\begin{array}{l}\text { Feldespar-Sericite Schist } \\
\text { (ATR1) }\end{array}$ & $\begin{array}{l}\text { Metavolcanics } \\
\text { (ATR2) }\end{array}$ \\
\hline \multicolumn{5}{|c|}{ Major oxides } \\
\hline $\mathrm{SiO}_{2}$ & 70.39 & 64.17 & 64.21 & 67.27 \\
\hline $\mathrm{Al}_{2} \mathrm{O}_{3}$ & 15.11 & 18.55 & 15.99 & 15.58 \\
\hline $\mathrm{Fe}_{2} \mathrm{O}_{3}$ & 2.72 & 5.69 & 6.85 & 6.04 \\
\hline $\mathrm{LiO}$ & 4.96 & 5.89 & 2.43 & 1.57 \\
\hline $\mathrm{Na}_{2} \mathrm{O}$ & 1.44 & 1.06 & 4.43 & 3.67 \\
\hline $\mathrm{MgO}$ & 1.15 & 1.5 & 1.59 & 1.84 \\
\hline $\mathrm{K}_{2} \mathrm{O}$ & 2.62 & 2.15 & 1.69 & 1.27 \\
\hline $\mathrm{TiO}$ & 6.65 & 0.69 & 1.63 & 0.68 \\
\hline Mn & 0.11 & 0.16 & 0.08 & 0.05 \\
\hline $\mathrm{P}_{2} \mathrm{O}_{5}$ & 0.02 & 5.16 & 0.19 & 0.2 \\
\hline $\mathrm{CaO}$ & 0.83 & 0.1 & 0.88 & 1.82 \\
\hline Total & 106 & 105.08 & 99.97 & 99.99 \\
\hline \multicolumn{5}{|c|}{ Trace elements } \\
\hline $\mathrm{Cu}$ & 28 & 153.1 & 67.5 & 14.8 \\
\hline $\mathrm{Cr}$ & 222.3 & 147.6 & 149.5 & 67.9 \\
\hline Mn & 786 & 1342.8 & 536.8 & 708.5 \\
\hline $\mathrm{Sr}$ & 111.1 & 34.6 & 267 & 162.3 \\
\hline $\mathrm{Zr}$ & 195 & 274.1 & 162.5 & 157.6 \\
\hline $\mathrm{Ba}$ & 182.6 & 1939 & 384.5 & 598.8 \\
\hline $\mathrm{Rb}$ & 73.3 & 67.2 & 41.7 & 37.6 \\
\hline $\mathrm{pb}$ & 11.7 & 12.3 & 9.4 & 5.5 \\
\hline $\mathrm{Ni}$ & 17.7 & 54.7 & 18.4 & 9 \\
\hline $\mathrm{Zn}$ & 51.7 & 107.2 & 62.4 & 71.6 \\
\hline Co & 1.3 & 14.3 & 10.5 & 7.9 \\
\hline $\mathrm{Cd}$ & 4.4 & 5 & 5.8 & 5.3 \\
\hline $\mathrm{Hg}$ & bdl & bdl & bdl & bdl \\
\hline $\mathrm{Sb}$ & bdl & bdl & bdl & bdl \\
\hline Cs & bdl & bdl & bdl & bdl \\
\hline $\mathrm{Ce}$ & 29.4 & 55.1 & 27.7 & 29.7 \\
\hline $\mathrm{U}$ & 3.3 & 4.1 & 0.5 & 0.1 \\
\hline $\mathrm{V}$ & 193.4 & 162.7 & 89.4 & 88.3 \\
\hline
\end{tabular}




\subsection{Hydrogeochemistry}

The analytical results and summery statistics (mean, minimum, maximum and standard deviation) of selected elements in water samples from Asgede Tsimbla sub catchment area are presented (Table 2). It gives the analytical techniques for different elements/parameters and shows how many orders of magnitude the natural concentration of the analyzed elements cover in this data set. It provides additional information on water standards [6]-[8] and show the percentage of samples above maximum acceptable concentrations (MAC) limits.

\subsubsection{Major Ions}

The collected surface and ground water samples ware analyzed for Major cations $\left(\mathrm{Ca}^{2+}, \mathrm{Mg}^{2+}, \mathrm{Na}^{+}\right.$and $\left.\mathrm{K}^{+}\right)$and anions $\left(\mathrm{Cl}^{-}, \mathrm{NO}_{3}^{-}\right.$and $\left.\mathrm{SO}_{4}^{2-}\right)$ and only two major ions (i.e. $\mathrm{Mg}^{2+}$ and $\mathrm{NO}_{3}^{-}$) ware exceeded the quality standards set for drinking water (Table 2). In terms of chemical composition (Appendix B) generally classifies as: about $60 \%$ of the samples have $\mathrm{Mg}$ and the rest has Ca followed by $\mathrm{Na}$ as dominating cations; according to anion $\mathrm{NO}_{3}$ as dominate and $\mathrm{Cl}$ followed by $\mathrm{SO}_{4}$. The water composition can also be arranged as $\mathrm{Mg}^{2+}+\mathrm{Ca}^{2+}>$ $\mathrm{Na}^{+}+\mathrm{K}^{+}$and $\mathrm{SO}_{4}^{2-}+\mathrm{Cl}^{-}>\mathrm{NO}_{3}^{-}+\mathrm{CO}_{3}^{2-}$.

\subsubsection{Trace Elements}

Out of 35 trace element analysis the following seven elements show value exceeding the maximum acceptable concentration (MAC) limits (Table 2): $\mathrm{Br}, \mathrm{Al}, \mathrm{Fe}, \mathrm{F}, \mathrm{As}, \mathrm{Pb}$ and $\mathrm{U}$ (WHO standards).

1) Bromine

The results of bromine ranges from $0.11-1.48 \mathrm{mg} / \mathrm{l}$ with mean value of $0.67 \mathrm{mg} / \mathrm{l}$. In the study area $1.48 \mathrm{mg} / \mathrm{l}$ is maximum in the ground water whereas $0.93 \mathrm{mg} / \mathrm{l}$ has to be in the surface water.The highest bromine value (AT-15) (Appendix B) is found in the borehole around Mai Lomine Village. All the results are found to be above WHO maximum allowable level- $0.01 \mathrm{mg} / \mathrm{l}$ (Table 2). The spatial distribution of fluorine is shown on (Figure 5).

Table 2. Range, Mean and standard deviation of the analytical data for selected elements in water samples and their comparison with different water standards.

\begin{tabular}{|c|c|c|c|c|c|c|c|c|c|}
\hline \multirow[b]{2}{*}{ Parameters } & \multirow[b]{2}{*}{ Techniques } & \multirow[b]{2}{*}{ Units } & \multirow[b]{2}{*}{ Range } & \multirow[b]{2}{*}{ Mean } & \multirow{2}{*}{$\begin{array}{c}\text { Std. } \\
\text { Deviation }\end{array}$} & \multicolumn{3}{|c|}{ Standards (MAC) } & \multirow{2}{*}{$\begin{array}{c}\text { >MAC } \\
\text { (\%) }\end{array}$} \\
\hline & & & & & & $\begin{array}{l}\text { WHO } \\
(2004)\end{array}$ & $\begin{array}{c}\text { Ethiopian } \\
\text { (2002) }\end{array}$ & $\begin{array}{c}\text { USEPA } \\
\text { (1997) }\end{array}$ & \\
\hline As & ICP-MS & $\mu \mathrm{g} / \mathrm{l}$ & bdl-23.7 & 2.47 & 6.73 & 10 & 10 & 10 & 10 \\
\hline $\mathrm{Pb}$ & ICP-MS & $\mu \mathrm{g} / \mathrm{l}$ & bdl-24.6 & 1.24 & 5.34 & 10 & 20 & 10 & 5 \\
\hline $\mathrm{Al}$ & ICP-MS & $\mu \mathrm{g} / \mathrm{l}$ & bdl-553 & 73.75 & 137.76 & 200 & 400 & $50-200$ & 30 \\
\hline $\mathrm{Fe}$ & ICP-MS & $\mu \mathrm{g} / \mathrm{l}$ & bdl-1939 & 1.49 & 3.69 & 300 & 400 & 300 & 20 \\
\hline $\mathrm{Cd}$ & ICP-MS & $\mu \mathrm{g} / \mathrm{l}$ & bdl-0.21 & 0.068 & 0.048 & 3 & 3 & 3 & - \\
\hline $\operatorname{Tm}$ & ICP-MS & $\mu \mathrm{g} / \mathrm{l}$ & bdl-0.40 & 0.031 & 0.068 & - & - & 2 & - \\
\hline $\mathrm{Ni}$ & ICP-MS & $\mu \mathrm{g} / \mathrm{l}$ & bdl-0.255 & 0.04 & 0.06 & 20 & & - & - \\
\hline Co & ICP-MS & $\mu \mathrm{g} / \mathrm{l}$ & bdl-0.56 & 0.122 & 0.138 & - & - & - & - \\
\hline Se & ICP-MS & $\mu \mathrm{g} / \mathrm{l}$ & bdl-13.99 & 2.16 & 3.04 & 10 & 10 & 10 & 5 \\
\hline $\mathrm{U}$ & ICP-MS & $\mu \mathrm{g} / \mathrm{l}$ & $0.05-4.32$ & 0.88 & 1.10 & 2 & - & - & 5 \\
\hline $\mathrm{Br}$ & IC & $\mathrm{mg} / \mathrm{l}$ & $0.11-1.48$ & 0.67 & 0.405 & 0.01 & - & 0.01 & 100 \\
\hline F & IC & $\mathrm{mg} / \mathrm{l}$ & $0.21-16.5$ & 1.86 & 4.12 & 1.5 & 3.0 & 4.0 & 20 \\
\hline $\mathrm{NO}_{3}$ & IC & $\mathrm{mg} / \mathrm{l}$ & $0.01-51.8$ & 11.93 & 1.75 & - & 50 & 10 & 10 \\
\hline $\mathrm{SO}_{4}$ & IC & $\mathrm{Mg} / \mathrm{l}$ & $1.12-435$ & 69.5 & 8.1582E1 & 500 & - & - & - \\
\hline $\mathrm{Mg}$ & ICP-AES & $\mathrm{mg} / \mathrm{l}$ & 7.56 - 127 & 59.68 & 3.3952E1 & - & - & - & - \\
\hline $\mathrm{pH}$ & & & $6.11-8.3$ & 7.12 & 0.653 & - & $6.5-8.5$ & $6.5-8.5$ & \\
\hline
\end{tabular}

Note: $->$ MAC $^{*}(\%)=$ greater than Maximum acceptable concentration for number of samples in percentage. 


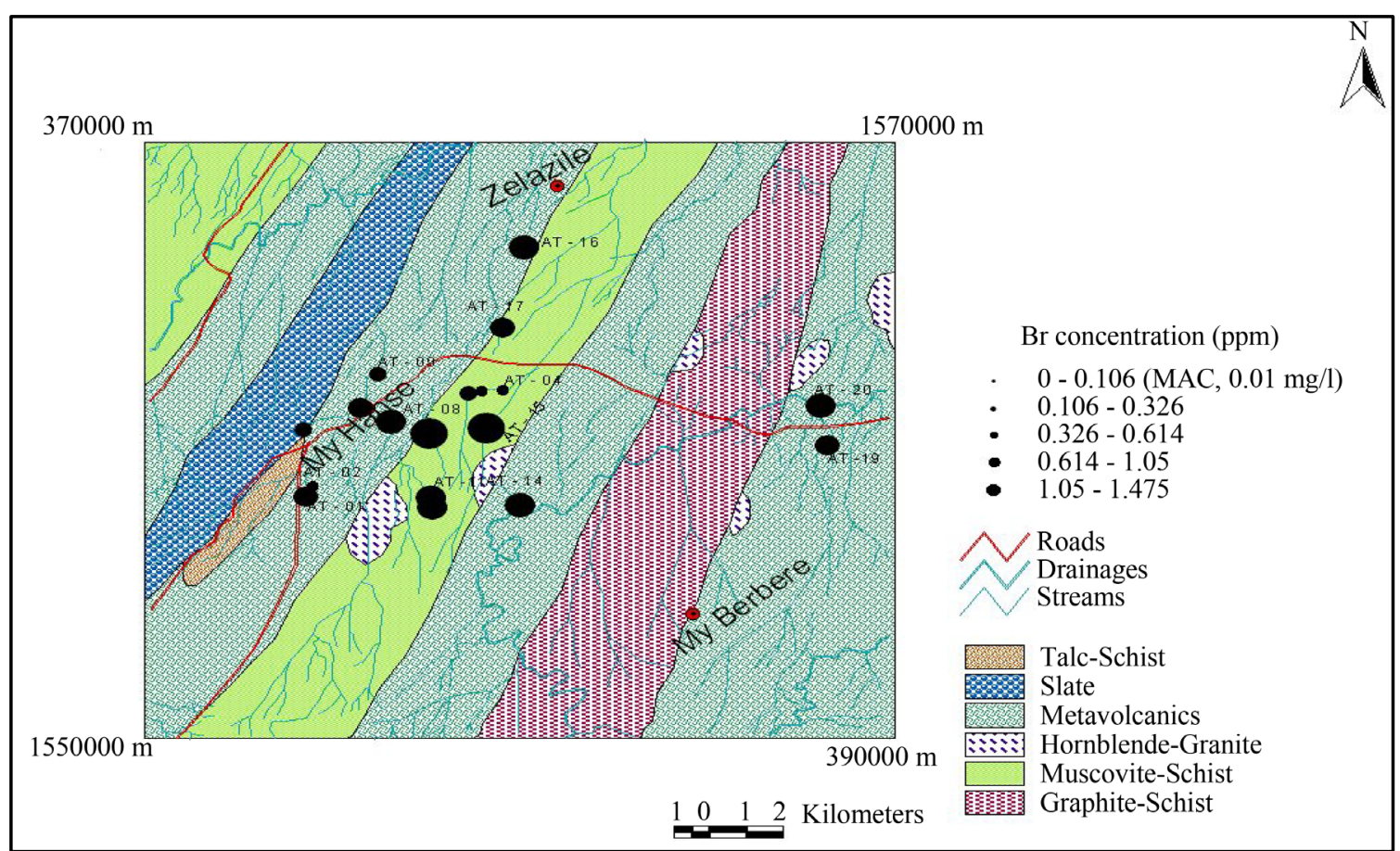

Figure 5. Spatial distribution of bromine concentration in surface and ground waters of Asgeda Tsimbla sub catchment area. Maximum admissible concentration (MAC) is also given in bracket.

\section{2) Fluorine}

The surface and ground water collected from various sites of Asgede Tsimbla area contained fluorine of 0.21 - $16.49 \mathrm{mg} / \mathrm{l}$ with an average value of $1.18 \mathrm{mg} / \mathrm{l}$ (Table 2). The maximum value of $16.49 \mathrm{mg} / \mathrm{l}$ recorded in sample (AT-16) (Appendix B) collected from borehole at Sembel Village, NE of Mai-Hanse Town, while the maximum value of $0.79 \mathrm{mg} / \mathrm{l}$ collected from surface water. Four of the samples indicate values higher than Maximum allowable limit (1.5 mg/l) of WHO (2004) drinking water guideline (Table 3). The spatial distribution of fluorine is shown on Figure 6.

3) Aluminium

The surface and ground water collected from various sites of Asgede Tsimbla area contained Al from less than the detection limit $(0.01 \mathrm{ppb})$ up to $553 \mathrm{ppb}$, with an average value of $73.75 \mathrm{ppb}$ (Table 2). The highest concentration of Al was observed in a sample (AT-07) (Appendix A) collected from borehole near Mai Hanse Town while in surface water $155 \mathrm{ppb}$ was observed as a maximum value. $30 \%$ of the sample value indicates above MAC (i.e. $100 \mu \mathrm{g} / \mathrm{l}$ ) based Canadian guideline for drinking water (1996).

4) Arsenic

The concentration of arsenic ranges from less than the detection limit $(0.01 \mu \mathrm{g} / \mathrm{l})$ up to $23.7 \mu \mathrm{g} / \mathrm{l}$ with a mean value of $2.47 \mu \mathrm{g} / \mathrm{l}$ (Table 1). $23.7 \mu \mathrm{g} / \mathrm{l}$ is maximum concentration in ground water while $20.2 \mu \mathrm{g} / \mathrm{l}$ in the surface water. The highest values was recorded in samples (AT-10 and AT-11) (Appendix A) collected around Fesfesay River, where intensive artisanal gold mining had been taking place and is located south-south east of Mai Hanse Town. Only two samples (10\%) fall above MAC of As $(10 \mu \mathrm{g} / \mathrm{l})$ in the study area.

5) Selenium

The value of Se varied from less than detection limit (0.01 ppb)-13.9 ppb with an average value of 2.16 $\mu \mathrm{g} \cdot \mathrm{L}^{-1}$. In the study area the maximum value in ground and surface water was recorded as $13.9 \mathrm{ppb}$ and $4.70 \mathrm{ppb}$ respectively and only one sample (AT-20) exceeds the WHO safe limits (Appendix A). The maximum value of 13.9 ppb (AT-20) was observed in a sample collected from Mai-Hammar River, where artisanal gold mining practices had been caring out.

\subsection{Stream Sediment Geochemistry}

The analytical results and summery statistics value of stream sediments are listed (Table 3). It gives additional 
Table 3. Analysis results of heavy metals in stream sediments (ppm) and its mean value in comparison with world geochemical background value in average shale.

\begin{tabular}{|c|c|c|c|c|c|c|c|c|}
\hline Sample no. & $\mathrm{Zn}$ & $\mathrm{Ni}$ & $\mathrm{Pb}$ & $\mathrm{Cu}$ & Co & $\mathrm{Ag}$ & $\mathrm{Cr}$ & Mn \\
\hline ASG-01 & 70 & 33 & 1 & 42 & 39 & 1.4 & 77.8 & 539 \\
\hline ASG-02 & 79 & 65 & 9 & 71 & 52 & 1.5 & 68.9 & 708. \\
\hline ASG-03 & 59 & 24 & 5 & 29 & 30 & 1.1 & 131 & 359 \\
\hline ASG-04 & 63 & 37 & 5 & 38 & 34 & 1.2 & 227 & 451 \\
\hline ASG-05 & 63 & 44 & 4 & 45 & 37 & 1.3 & 154 & 1100 \\
\hline ASG-06 & 71 & 34 & 3 & 45 & 30 & 1.2 & 188 & 410 \\
\hline ASG-07 & 105 & 37 & 6 & 44 & 29 & 1.2 & 171 & 399 \\
\hline ASG-08 & 66 & 29 & 4 & 32 & 22 & 1.9 & 172 & 265 \\
\hline ASG-09 & 33 & 18 & 3 & 20 & 24 & 2.0 & 160 & 536 \\
\hline ASG-10 & 64 & 28 & 3 & 30 & 19 & 1.76 & 149 & 255 \\
\hline ASG-11 & 76 & 32 & 8 & 38 & 21 & 2.2 & 147.6 & 354 \\
\hline ASG-12 & 68 & 29 & 8 & 34 & 24 & 2.1 & 151.2 & 231 \\
\hline ASG-13 & 57 & 26 & 5 & 30 & 20 & 1.6 & 143 & 350 \\
\hline ASG-14 & 78 & 36 & 6 & 43 & 25 & 1.8 & 128.4 & 255 \\
\hline ASG-15 & 50 & 22 & 7 & 29 & 18 & 2.3 & 164.6 & 354 \\
\hline ASG-16 & 107 & 54 & 12.3 & 37 & 19 & 2.2 & 132.4 & 229 \\
\hline ASG-17 & 84.7 & 41 & 11.4 & 31.6 & 32 & 2.4 & 136.2 & 260 \\
\hline ASG-18 & 86 & 45 & 13.6 & 33 & 37 & 2.7 & 147.6 & 786 \\
\hline ATS-19 & 26.3 & 18 & 16.5 & 11 & 48 & 5.2 & 251.3 & 623 \\
\hline ATS-20 & 48.9 & 19 & 6.5 & 75 & 54 & 5.3 & 160.6 & 478 \\
\hline Minimum & 26.3 & 18 & 1 & 11 & 18 & 1.1 & 68.9 & 229 \\
\hline Maximum & 107 & 65 & 16 & 75 & 54 & 5.3 & 251 & 1100 \\
\hline Mean & 67.7 & 33.55 & 6.86 & 37.8 & 30 & 2.1 & 152.8 & 447.1 \\
\hline Average shale $^{\mathbf{a}}$ & 95 & 68 & 20 & 45 & 19 & - & 90 & 850 \\
\hline
\end{tabular}

Average shale ${ }^{\mathrm{a}}$ : world gechemical background value in average shale [9].

information on world geochemical background value in average shale of each element concentration.

\section{Discussion}

\subsection{Lithogeochemistry}

The composition of surface waters and shallow ground waters will closely reflect the local geology. Weathering acting on mineral deposits contributes to promote a local rise of the contents of major, minor and trace elements. These anomalous can be identified in soil, stream sediment and waters [10].

In terms of trace and major element analysis the mtavolcanics, Feldespar-Sericite Schist and graphite schist samples are enriched with $\mathrm{Mo}, \mathrm{Cu}, \mathrm{Mn}, \mathrm{Cr}$, and $\mathrm{Rb}$ elements and have high $\mathrm{SiO}_{2}, \mathrm{Al}_{2} \mathrm{O}_{3}, \mathrm{Fe}_{2} \mathrm{O}_{3}$ and $\mathrm{LIO}$ as major oxides (Table 3). Concentration of these elements vary widely among rock types; so health issue related to water interaction with rocks are different according to the geographic distribution of the rock types.

The chemical transmission of health risk in fact began from rocks with enhanced or reduced contents of elements of greater significant for life [10]. Health issue related to water and stream sediments in the study area are generally derived from the basement rocks upon weathering. Stream waters drained through soil waste disposals from artisanal gold panning sites, which could contain high level of contaminants are supposed to be as a 


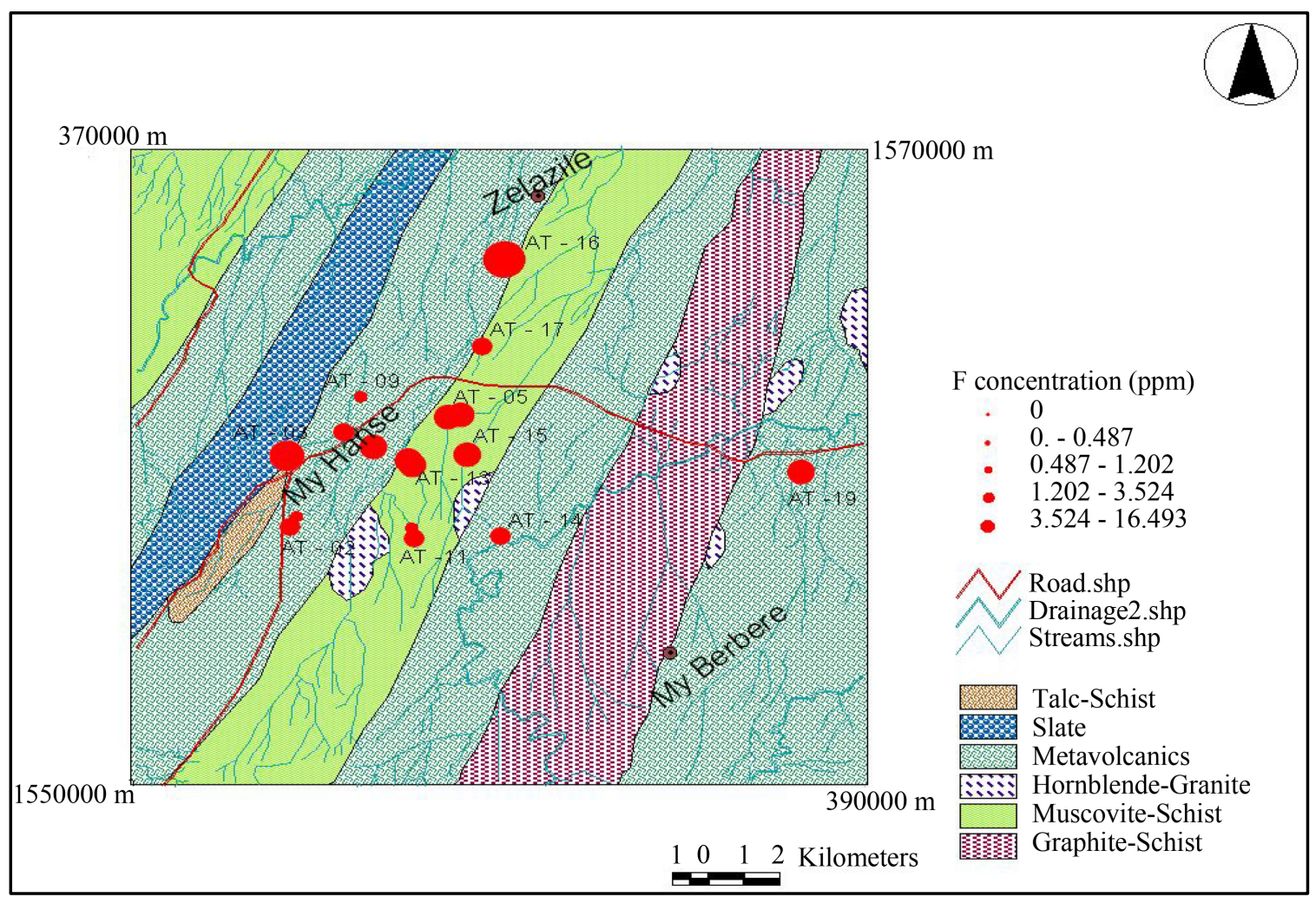

Figure 6. Spatial distribution of fluorine concentration in surface and ground waters of Asgeda Tsimbla sub catchment area.

secondary source of water pollution in the area. Agricultural fertilizers and pestsides released in to the soil might be also considered as important factors in concentration of some trace elements in surface and ground water of the area.

\subsection{Hydrogechemistry}

The chemical composition of rocks, mineral and soils through which the groundwater flows causes very large variations of the chemistry of the ground water [11]. The ground and surface water in the study area is directly using as drinking water and obviously there is a link between water chemistry and health. The results of elements above MAC and elements which have health impact in its low level such as selenium are presented and discussed as follows. Selected parameters in geochemical environment as a cause of some diseases and their possible source of contaminants are presented (Appendix C).

Bromine: Maximum acceptable concentration (MAC) of $0.01 \mathrm{mg} / \mathrm{l}$ for bromine in drinking water has been established on the base of health consideration. All the results are found to be above WHO maximum allowable level $-0.01 \mathrm{mg} / \mathrm{l}$ (Table 2). The values of $\mathrm{Br}$ could be related to the use of fertilize and pestsides in agriculture and artisanal gold mining practice.

The bromine concentration in rocks, soils and freshwater usually are very small. The values of bromine in the study area could probably as bromine from mining, fertilizer and pesticides release into soil; in turn bromine leached from soils when they flooded into surface and ground water.

Some of health effects that can be caused by excess bromine value in water are malfunction of nervous system, gastrointestinal and disturbances in genetic material; and also cause damage to organs such as liver, kidneys, lungs, thyroid glands. Some forms of organic bromine, such as ethylene bromine, can even cause cancer [8].

Fluorine: The World Health Organisation (WHO) guideline value for fluorine in drinking water is $1.5 \mathrm{mg} / \mathrm{l}$, but in most samples about (55.5\%) of the fluoride contents were above the $0.5 \mathrm{mg} / \mathrm{l}$, the limit recommended for tropical countries by WHO [10]. Some other researchers have been suggested $0.7 \mathrm{mg} / \mathrm{l}$ as an action level for 
tropical countries with high daily intake of water [8]-[10] have also been noted the WHO recommended levels of $1.5 \mathrm{mg} / \mathrm{l}$ fluorine in drinking waters are not acceptable for hot and dry climate.

Fluoride enrichment in the surface and ground water could be related to leaching of rocks rich in fluorine such as granite (i.e. as granite sample in the study area constitute fluorine bearing minerals such as biotite, hornblende and sphene) and muscovite-schist, where this rock unit also contains muscovite, biotite and feldspar minerals which are considered as fluorine rich minerals. Rock-water and soil-water interaction; weathering and leaching of fluorine bearing rocks and minerals could be considered as important factors in the concentration of fluoride in the surface and ground water.

Excessive intake of fluoride rich- water can cause dental fluorosis (mottling of teeth), skeletal fluorosis (depilating disease, which affect bones) and harm nerves and muscles. The high fluoride is not only possible risk factor but it is possible that there is some relationship with the disease or it could even increase the severity of the disease [1]. Many animal experiments reported that the kidney damage can occur even at low levels of fluoride exposure over large period of time [12].

Aluminium: The study area show maximum level in ground water to be $553 \mathrm{ppb}$. As $\mathrm{Al}$ is found in most rocks abundantly, the values could be related to natural sources (i.e. rocks, soils and their derivative minerals) and to some extent anthropogenic activities such as artisanal gold mining and agriculture. $\mathrm{Al}$ in the surface and ground water could be derived from weathering of rocks rich in $\mathrm{Al}$ and leaching of soils accumulated from such activities as artisanal gold mining and agriculture.

Aluminium is included in the priority list of hazardous substance identified by agency for toxic substance and disease register (ATSDR). Sign and symptoms of aluminium toxicity include colic, dementia, esophagitis, gastroenteritis, kidney damage and liver damage [8].

Arsenic: The high amount of arsenic value in water of Asgede area could be introduced through anthropogenic activities (i.e. artisanal gold mining) and the dissolution of arsenic containing bed rock (Phylite/Slate) and minerals such as pyrite and chalcopyrite.

Ingesting inorganic arsenic contaminated drinking water cause skin cancer, tumours of the bladder, kidney, liver (the primary carcinogen) and lungs. High level of in organic arsenic in food or water can be fatal, a high level 60 parts per million parts of food or water (60 ppm) [8]. Adverse health effects of too high arsenic value in drinking waters have recently received much attention [13].

Selenium: The selenium concentration in waters are generally very low and only rarely exceeds the WHO safely limits of $10 \mu \mathrm{g} / \mathrm{l}$ [14]. The study area show about $40 \%$ of the sample analysed was $<1 \mu \mathrm{g} / \mathrm{l}$ and only one sample (AT-20) exceeds the WHO safe limits and this could be related to artisanal gold mining practise in that river.

Concentration of selenium in fresh water around the world is $0.2 \mu \mathrm{g} / \mathrm{L}$ [15], in Asgede Tsimbla area selenium concentration in some well waters observed as low as $0.01 \mu \mathrm{g} / \mathrm{L}$.

Selenium appears to be essential element in human nutrition. It is part of the biological important enzyme glutathione peroxydase (PHS-PX) which acts as antioxidant preventing tissue degeneration. Selenium prevents the toxicity of several other metals such as silver, mercury, cadmium and lead. Selenium, at trace levels is essential in human and animal diet and its deficiency has received much attention. It causes symptoms such as muscular degeneration, impeded growth, fertility disorders, anemia and liver disease [16]. Keshan and Kaschin-Beck disease reported on regional scale from China, are caused by Se deficiency. The recommended daily intake described by many researchers and agencies for Se is about $35 \mu \mathrm{g}$ per day and doses larger than $200 \mu \mathrm{g}$ can be toxic [17]. Other researchers e.g. Fordyce et al. [14]; Yang and Xia [18] had noticed deficiency level (<11 $\mu \mathrm{g} / \mathrm{g}$ per day) and toxic level (>900 $\mathrm{\mu g} / \mathrm{g}$ per day) for selenium. Anyway Se is an element that should better have a minimum guideline level by WHO.

Iron and magnesium falls above MAC, but there is no evidence of adverse health effects specifically attribute to these elements in drinking water, and are more aesthetic nature (cause undesirable test and odor to the water) or limit the use of water for practical purpose.

\section{Bivariate Correlations}

$\mathrm{Cu}$ and Se show similarity in distribution pattern and have positive correlation. The trend between $\mathrm{Cu}$ and Se could origin from dissolution of sulfide minerals. The similar behavior of $\mathrm{Cu}$ and Se can be explained by their geochemical similarity, which are Chalcophile elements (prefer to bond with sulfur). The trend between $\mathrm{Al}$ and Fe also indicate strong positive correlation. This could be interpreted as indicative of common source for them. 
Table 4. US EPA guidelines for sediment quality as compared to present study-Asgeda area.

\begin{tabular}{ccccc}
\hline Metal & Not polluted & Moderately polluted & Heavily polluted & Present study \\
$\mathrm{Ag}$ & - & - & - & $1.1-5.3$ \\
$\mathrm{Cu}$ & $<25$ & $25-50$ & $>50$ & $11-75$ \\
$\mathrm{Ni}$ & $<20$ & $20-50$ & $>50$ & $18-65$ \\
$\mathrm{~Pb}$ & $<40$ & $40-60$ & $>60$ & $1.1-5.3$ \\
$\mathrm{Co}$ & - & - & - & $18-54$ \\
$\mathrm{Cr}$ & $<25$ & $25-75$ & $>75$ & $68.9-251$ \\
$\mathrm{Mn}$ & $<300$ & $300-500$ & $>500$ & $229-1100$ \\
\hline
\end{tabular}

Fluorine show negative correlation with bromine and this could indicate that they have different origin.

\subsection{Stream Sediment Geochemistry}

The accumulation of heavy metals in sediments can be a secondary source of water pollution, once environmental condition is changed [19]. There for an assessment of heavy metal contamination in sediment is an important tool to assess the risk of hydrogeochemical environment. Assessments of metal contaminants in the area are discussed bellow.

\section{Assessment According to United State Environmental Protection Agency (US EPA)}

The chemical contamination in sediments was evaluating by comparison with sediment quality guideline proposed by US EPA. These criteria are shown (Table 4). $\mathrm{Pb}$ in all stations under investigation was belong to unpolluted sediments, while elements $\mathrm{Cu}, \mathrm{Ni}$ and $\mathrm{Mn}$ are considered as moderately polluted and $\mathrm{Cr}$ more or less belong to heavily polluted.

\section{Conclusions}

The ground and surface water in some zones of the study area has values of $\mathrm{Br}, \mathrm{F}, \mathrm{Al}, \mathrm{As}, \mathrm{Pb}, \mathrm{U}, \mathrm{Fe}, \mathrm{Mg}$ and $\mathrm{NO}_{3}$ exceeding MAC guideline standards for water. $\mathrm{Br}$ and $\mathrm{F}$ account for almost all the elevated values. The association of $\mathrm{F}, \mathrm{Br}$ and $\mathrm{Cl}$ is found as geochemical indicator of liver cancer in areas such as Parana-Brazil, China and Srilanka [20].

Trace elements like Cd, Cr, pb, Be, and Tm which have serious health effects fall to pass quality standards set for drinking water. Only two sample sites fall above MAC for As and these may not considered as a major problem in the area. From present study the water quality is therefore better than expected. The ground water is generally weak acidic to basic and the dominate ions are $\mathrm{Mg}$ and $\mathrm{NO}_{3}$.

It is clear that health relates not only to excesses of trace elements in drinking water supplies, but may also relate to deficiencies (e.g. Se). The majority of water and stream sediment samples of analyzed results in the study area show significantly low as compared to worldwide values of Se for these geochemical medias.

The accumulation of heavy metals in sediments can be a secondary source of water pollution once environmental condition is changed [19]. The Geo-Accumulation Indexes (Igeo) of some heavy metals such as chromium, cobalt, copper, and lead are calculated for stream sediment quality in the study area and give values from unpolluted to moderately polluted.

Although liver related disease has been identified around shire area, the causes of the disease remain unclear. Environmental factors are mostly considered to explain the etiology of this liver related disease.

\section{Acknowledgements}

This work was financially supported by Mekelle University-MU-ULD-project on Liver related diseases in Shire area. Constructive and helpful comments by Kassa Amare (Dr.) and Beheemalingeswara Konka (Prof.) were greatly appreciated.

\section{References}

[1] Tigray Health Bureau (2009) Report on unidentified Disease in North Western Zone of Tigray. 
[2] Oasis Foundation of Ethiopia (2009) Reports on the Investigation of Liver Related Mortality in Shire Area, Western Tigray.

[3] Santra, S.C. (2001) Environmental Science. New Central Book Agency. (P). Ltd, Calcutta, 944.

[4] Dissanayake, C.B. (1991) The Fluoride Problem in Ground Water of Srilanka Environmental Management and Health. International Journal of Environmental Studies, 38, 195-203. http://dx.doi.org/10.1080/00207239108710658

[5] National Meteorological Service Agency (NMSA) (2008) Climate of Ethiopia. Series Vol. II No. 2 Rainfall, Open File Materials from National Meteorological Service Agency, 135.

[6] WHO (2004) Guideline for Drinking Water Quality. World Health Organization, Geneva.

[7] Ethiopian (2001) Guideline for Drinking Water Quality. Ministry of Water and Resource, Addis Ababa.

[8] US EPA (2001) National Primary Drinking Water regulations. EPA 816-F-01-007, United State Environmental Protection Agency.

[9] Turkian, K.K. and Wedpohl, K.H. (1961) World Geochemical Background Value in Average Shale for Metals in Stream Sediments. Geological Society of America Bulletin, 72, 175-191.

[10] Komatina, M. (2001) Geochemistry of Ground Water and Pollution. Journal of African Earth Science, 33, $363-376$.

[11] Davis, S.N. (1966) Hydrogeology. John Wiley and Sons, Inc., New York, London and Sydney, 463 p.

[12] Liu, W.W. (2005) The Study on Etiology of Hepatocytic Liver Cancer. Shijie Huarne, 7, 93-97.

[13] Smith, B. (2000) The Bioaccessibility of Essential and Potentially Toxic Trace Elements in Tropical Soils from Mukono District, Uganda. Part 5, Geological Society of London Spatial Publication, Vol. 157, 885-891.

[14] Fordyce, F.M., Zhang, G., Green, K. and Liu, X. (2000) Soil, Grain and Water Chemistry in Relation to Human Selenium-Responsive Diseases in Enshi District, China. Applied Geochemistry, 15, 117-132. http://dx.doi.org/10.1016/S0883-2927(99)00035-9

[15] Wang, Z.Q. (1991) Relationship between Sources of Drinking Water, Water Quality Improvement, and Gastric Cancer Mortality in Change Country. World Journal of Gastroenterology, 4, 45-47. http://dx.doi.org/10.3748/wjg.v4.i1.45

[16] Lag, J.A. (1984) Comparisons of Selenium Deficiency in Scandinavia and China. Ambio, 13, 186-187.

[17] FDA (1998) Maximum Value Recommended Daily Intake of Vitamins and Minerals for Humans.

[18] Yang, G. and Xia, Y.M. (1995) Study on Human Dietary Requirements and Safe Range of Dietary in Take of Selenium in China and Their Application to the Prevention of Related Endemic Disease. Biomedical and Environmental Sciences, 8, 187-201.

[19] Cheung, K.C., Poon, B.H.T., Lan, C.Y. and Wang, M.H. (2003) Assessments of Metal and Nutrient Concentrations in River Water and Sediment Collected from the Cities in the Pearl River Delta, South China. Chemosphere, 52, 14311440. http://dx.doi.org/10.1016/S0045-6535(03)00479-X

[20] Islam, M.R., Lahermo, P., Salmanin, R., Rojestaczer, S. and Peuroniami, V. (2000) Lake and Resiorvior Water Quality Affected by Metals Leaching from Tropical Soil Srilanka. Environmental Geochemistry, 39, 31-35.

\section{Web Sources}

http://www.bgs.ac.uk.dfid-kar-gscience/metadata/webtolkit/home.html

http://home.swipnet.se/medicalgeology

http://archive.unu.edu/env/Arsenic/Dhaka2003/00-Content.pdf

http://www.unizh.ch/amicroeco/uni/kurs/mikock/results/projectz/arsenihtml 
Appendices

Appendix A. Trace element chemical analysis of water samples.

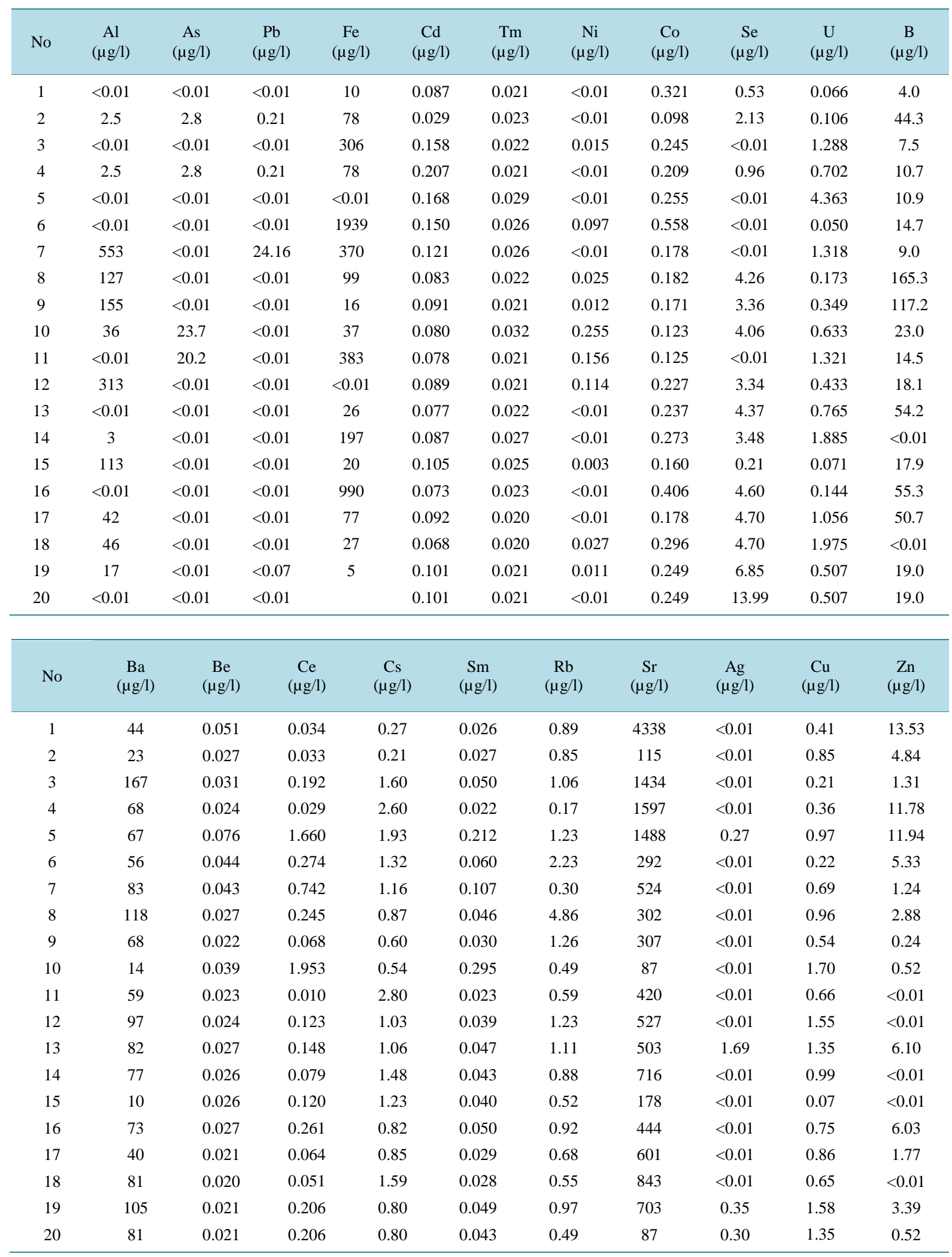




\begin{tabular}{|c|c|c|c|c|c|c|c|c|c|c|}
\hline Sample No & $\mathrm{F}$ & $\mathrm{Br}$ & $\mathrm{NO}_{3}$ & $\mathrm{SO}_{4}$ & $\mathrm{HCO}_{3}$ & K & $\mathrm{Na}$ & $\mathrm{Ca}$ & $\mathrm{Mg}$ & Water type \\
\hline AT-01 & 0.3737 & 0.4743 & 0.3595 & 435.3391 & 299.8 & 1.3154 & 23.1404 & 252.8269 & 7.5592 & $\mathrm{Ca}-\mathrm{SO}_{4}-\mathrm{Cl}-\mathrm{HNO}_{3}$ \\
\hline AT-03 & 0.01 & 0.883 & 51.3786 & 13.3591 & 278.75 & 3.9794 & 7.5569 & 29.6082 & 93.5829 & $\mathrm{Mg}-\mathrm{HNO}_{3}-\mathrm{Cl}$ \\
\hline AT-05 & 0.6964 & 0.1067 & 24.5498 & 22.7953 & 872.00 & 2.3244 & 77.1731 & 112.5096 & 30.9147 & $\mathrm{Sr}-\mathrm{Na}-\mathrm{HCO}_{3}$ \\
\hline AT-06 & 1.0424 & 0.2695 & 8.8919 & 46.0297 & 616.00 & 2.664 & 128.897 & 90.3463 & 47.5582 & Ca-Na-Mg- $\mathrm{HCO}_{3}$ \\
\hline AT-07 & 3.5244 & 0.4623 & 0.198 & 182.4118 & 740.18 & 3.5602 & 166.7217 & 60.4901 & 41.0573 & $\mathrm{Na}-\mathrm{HCO}_{3}-\mathrm{Cl}-\mathrm{SO}_{4}$ \\
\hline AT-08 & 0.2506 & 0.2031 & 0.0069 & 58.8343 & 538.34 & 8.3995 & 24.2788 & 36.4384 & 16.9719 & Ca-Mg-Na- $\mathrm{HCO}_{3}-\mathrm{Cl}-\mathrm{SO}_{4}$ \\
\hline AT-09 & 0.7904 & 0.3267 & 1.0275 & 150.7578 & 116.32 & 3.2922 & 75.1462 & 42.7848 & 20.1805 & $\mathrm{Na}-\mathrm{Ca}-\mathrm{HCO}_{3}-\mathrm{Cl}-\mathrm{SO}_{4}$ \\
\hline AT-10 & 0.01 & 0.9031 & 34.5338 & 16.3117 & 191.96 & 4.7115 & 13.3544 & 36.8005 & 126.7885 & Mg-Ca \\
\hline AT-11 & 0.3396 & 0.9303 & 18.7139 & 21.5874 & 0.17 & 5.5722 & 35.1257 & 45.7797 & 103.3873 & Mg-Ca-Na \\
\hline AT-12 & 0.01 & 1.3663 & 0.5617 & 159.1126 & 55.63 & 1.4776 & 112.6191 & 8.8124 & 87.104 & $\mathrm{Mg}-\mathrm{Na}-\mathrm{HCO}_{3}-\mathrm{Cl}$ \\
\hline AT-13 & 0.747 & 0.2089 & 1.6022 & 45.8517 & 718.71 & 4.0057 & 49.7108 & 39.4576 & 28.872 & Mg-Na-Ca-Cl-HCO ${ }_{3}$ \\
\hline AT-14 & 0.7309 & 0.9971 & 0.4488 & 226.5273 & 260.06 & 3.2033 & 78.7514 & 97.5354 & 54.7073 & $\mathrm{Ca}-\mathrm{Na}-\mathrm{SO}_{4}-\mathrm{HCO}_{3}-\mathrm{Cl}$ \\
\hline AT-15 & 0.4872 & 1.4755 & 2.4962 & 116.0967 & 263.07 & 2.2248 & 60.328 & 58.4001 & 75.0533 & Mg-Ca-Na-HCO ${ }_{3}-\mathrm{Cl}-\mathrm{SO}_{4}$ \\
\hline AT-16 & 1.2021 & 0.941 & 14.6134 & 145.5691 & 261.66 & 5.984 & 108.8469 & 106.7415 & 53.5304 & $\mathrm{Ca}-\mathrm{Na}-\mathrm{Mg}-\mathrm{HCO}_{3}-\mathrm{Cl}$ \\
\hline AT-17 & 16.4932 & 0.506 & 0.2541 & 1.1178 & 681.86 & 1.5381 & 47.1395 & 11.0219 & 68.832 & $\mathrm{Mg}-\mathrm{Cl}-\mathrm{HCO}_{3}$ \\
\hline AT-18 & 0.3493 & 0.6147 & 1.6146 & 105.3168 & 335.43 & 4.5565 & 52.6247 & 43.4327 & 91.0991 & $\mathrm{Mg}-\mathrm{Cl}-\mathrm{HCO}_{3}$ \\
\hline AT-19 & 0.3512 & 0.5082 & 1.7603 & 104.8366 & 316.93 & 4.5399 & 52.5605 & 43.365 & 91.0324 & $\mathrm{Mg}-\mathrm{Na}-\mathrm{Cl}$ \\
\hline \multirow[t]{2}{*}{ AT-20 } & 0.6599 & 1.0503 & 51.752 & 140.3853 & 62.12 & 1.8192 & 134.5995 & 110.9888 & 36.0528 & $\mathrm{Na}-\mathrm{ca}-\mathrm{Cl}-\mathrm{HCO}_{3}$ \\
\hline & & & & & 648.16 & & & & & \\
\hline
\end{tabular}

Appendix C. The occurrence of some disease and their possible contaminants. Selected parameters in geochemical environment (surface and groundwater) on the occurrence of some diseases and their possible source of contaminants.

\begin{tabular}{|c|c|c|c|c|}
\hline \multirow[t]{2}{*}{ Parameters } & \multirow[t]{2}{*}{$\begin{array}{l}\text { MAC ( } \mu \mathrm{g} / \mathrm{l}), \mathrm{WHO}, \\
\text { EU and Canadian }\end{array}$} & \multicolumn{2}{|c|}{ Potential health effects } & \multirow[t]{2}{*}{ Source of contaminants } \\
\hline & & Deficiency & Abundance & \\
\hline As & 10 & $\begin{array}{l}\text {-Insufficient hair growth } \\
\text {-Spleen enlargement }\end{array}$ & $\begin{array}{l}\text {-Skin cancer } \\
\text {-Tumours of bladder, kidney, liver and } \\
\text { lungs. }\end{array}$ & -Natural deposit, electronic waste. \\
\hline $\mathrm{Pb}$ & 10 & & $\begin{array}{l}\text {-Kidney, liver, heart and nervous system } \\
\text { damage. }\end{array}$ & -Natural and industrial deposits. \\
\hline Se & 10 & $\begin{array}{l}\text {-Breast, gastrointestinal and skin } \\
\text { cancer. } \\
\text {-Liver damage and heart muscle } \\
\text { disorder }\end{array}$ & $\begin{array}{l}\text {-Hair and nail loss } \\
\text {-Nervous disorder }\end{array}$ & $\begin{array}{l}\text {-Natural deposit, mining, smelting } \\
\text { and coal combustion }\end{array}$ \\
\hline $\operatorname{Tm}$ & 10 & & -Kidney, liver, brain and intestinal effects & -Electronic, drug and alloy \\
\hline $\mathrm{Br}$ & 10 & & $\begin{array}{l}\text {-Malfunctioning of nervous system } \\
\text {-Liver, kidney, lung and thyroid gland } \\
\text { damage. }\end{array}$ & -Natural deposit \\
\hline $\mathrm{Cr}$ & 50 & -Diabetes & $\begin{array}{l}\text {-Liver, kidney and circulatory system } \\
\text { disorders } \\
\text {-Lung cancer }\end{array}$ & $\begin{array}{l}\text {-Natural deposit, mining } \\
\text { electroplating. }\end{array}$ \\
\hline $\mathrm{Cu}$ & 1000 & -Anemia & -Gastrointestinal irritation & $\begin{array}{l}\text {-Natural/industrial deposit, wood } \\
\text { preservation }\end{array}$ \\
\hline $\mathrm{Al}$ & 100 & & $\begin{array}{l}\text {-Kidney and liver damage } \\
\text {-Dementia, colic and esophagitis }\end{array}$ & -Natural/industrial deposits \\
\hline
\end{tabular}




\begin{tabular}{|c|c|c|c|c|}
\hline \multicolumn{5}{|c|}{ Continued } \\
\hline $\mathrm{F}$ & 1500 & $\begin{array}{l}\text {-Developmental defects of bone } \\
\text { and teeth }\end{array}$ & -Dental and skeletal flourosis & -Natural deposits \\
\hline $\mathrm{NO}_{3}$ & 45,000 & & -Metamoglobulinemia & $\begin{array}{l}\text {-Animal waste, fertilizer and } \\
\text { natural deposit }\end{array}$ \\
\hline $\mathrm{Cd}$ & 10 & -Growth reduction & $\begin{array}{l}\text {-Kidney effects } \\
\text {-Cancer of prostate }\end{array}$ & $\begin{array}{l}\text {-Natural deposit } \\
\text {-Galvanized pipe corrosion }\end{array}$ \\
\hline
\end{tabular}

\section{Submit or recommend next manuscript to SCIRP and we will provide best service for you:}

Accepting pre-submission inquiries through Email, Facebook, LinkedIn, Twitter, etc.

A wide selection of journals (inclusive of 9 subjects, more than 200 journals)

Providing 24-hour high-quality service

User-friendly online submission system

Fair and swift peer-review system

Efficient typesetting and proofreading procedure

Display of the result of downloads and visits, as well as the number of cited articles

Maximum dissemination of your research work

Submit your manuscript at: http://papersubmission.scirp.org/ 